\title{
WORK VALUE AMONG MARRIED AND UNMARRIED PERSON': A COMPARATIVE STUDY
}

\author{
Ramesh O. Prajapati*
}

\begin{abstract}
Aim of the research is to find out the Work value among married and unmarried person's. So investigator selected two groups one is married and other is unmarried persons, both groups have 200persons. In one group has 113 married and other one groups has 87 unmarried persons. The all subjects were randomly selected. Data were collected from Ahmadabad district. Scale was use for data collection is personal datasheet and Work value scale developed by super (1970) and this scale was translated into Gujarati by Jalawadiya (2002), and data were analysis by ' $t$ ' test. Result show, There is no significant mean difference of Work value between married and unmarried persons. There is no significant difference of the Work value of joint and nuclear families. The high income persons work value is better than the low incomes.
\end{abstract}

\section{Introduction:}

Today in $21^{\text {st }}$ century occupational field become very extensive because of promptly developed many industry and machinery and also progress many occupational field. There is especially a teacher, clerk, doctor, manager, engineer, bank employee, worker, nurses, etc. can be considered. Each occupation has unique importance. All above its important occupation field of doctors and bank employee. Because of doctors occupation is very important in social by the viewpoint of humanity and moral.

Doctors and bank employees have to doing his work very careful. Otherwise his small mistake can create big problem. So, doctors and bank employees have needs to take care of his physical and mental health. His mentality can be do effect on his work and patient.

If they can understand his work value and psychological well-being very well so than they doing his duty very effectively. Its maximum benefit goes to patient and consumer. When doctors and bank employees keep attractive, liking and positive emotion

*Dept. of Psychology, SP University, Vallabh VidhyaNagar 388120, Gujarat

(C) www.ijip.in 
towards with his work than they to maintain his duty very effectively and when they thinking negative and dissatisfaction towards his work then they can't do his duty very well.

In psychology to occur many research for to get information about human behavior in deeply. But is very insufficient research doing on work value, burnout and psychological well-being its effect on human behavior.

Work related value or work value is a special usage of the general concept value and may be defined as the conception of what is "preferable" from among "the alternative modes of conductor and states" with respects to ones work activity. (punekur, 1989).

According to Rokeach (1973) "A value is an enduring belief that a specific mood of conductor and state of existence is personally or socially preferable to an opposite or converse mode of conductor and state of existence."

They contain a moral flavor in that they carry an individual's ideas as to what is right, good or desirable. Spranger (1928) describes values as the basic interests or motives in the personality of an individual.

Perstonjee (1985) views value "as the worth or excellence or the degree of worth ascribed to an object or a class there of. He further opines that value is a standard or yards tics to guide actions, attitudes, evaluations and justifications of the self and other."

Richard Morris (1956) defines values as either individuals or commonly held conceptions of the desirable. Franz Adler (1956) sees them as learned components of personalities identifiable only as probabilities that particular behavior will occur in a variety of circumstances.

According to Anantharaman (1980) "Anything that satisfies a human need becomes their by a value." value are considered, by some authors, as normative standards to judge and to choose among alternative modes of behavior (Becker \& Mcklintock, 1967; kluckhohn, 1952).

According to Suar (1992) "value are desirable ideals located centrally within one's belief system. These desirable ideals, therefore, determine what one ought to or ought not to do to activities they engage, in the professions they work, in the situation they live, in the objects they make or acquire and in the principal they accept or cultivate."

According to Amsa and punekur (1985), work values are usually defined as the individually held conceptions of what is desirable with respect to the rewards (extrinsic or intrinsic) from their work activity.

According to super Donald (1968), work values constitute various aspects of work. On the same lines, dhar (1967), in a study of work values of adolescent boys, defined work value as the aspects of work which guide and influence adolescent behavior. In a similar fashion, pestonjee (1985) define work value "as the worth or excellence ascribed to a particular aspect of work" in other words work values are value that pertained to the work situation and its concomitants.

(C) www.ijip.in 
Kalleberg (1977) says; work values represent the meaning that individuals attach to perceived job characteristics. He says, work may have a variety of meaning for individuals ........, work has no inherent meaning, but, rather individuals input such meaning to their work activity. One way to understand the variety of these meaning is to specify the range of gratification that are available from work in an industrial society and to assess the degree to which particular individuals value each of these dimensions. He further says "work values reflects the individual's awareness of the conditions he seeks from the work situation and regulate his actions in pursuit of that condition."

Mehta (1961) has defined the concept of values as ideas formed by each individuals worker as to how should he do his work. Jyoti verma (1985) has viewed work value "as a generalized preference where a person attached a sense of worth or excellence in doing his work well."

All the above definitions of value also apply to work value but their applicability is limited to aspects of work. However, an attempt is being made to present a few important definitions of work value enunciated by different investigators, before embarking on the explanation of important definitions of work value it is useful to distinguish value as well as work value from other related concept that have been used previously in the literature for similar purposes.

\section{Aims of the study:}

1. To study of the Work value among married and unmarried person's.

2. To study of the Work value among joint and nuclear families.

3. To study of the Work value among low and high income of families.

\section{Hypothesis:}

1. There is no significant difference between the Work value of married and unmarried person's.

2. There is no significant difference between the Work value of joint and nuclear families.

3. There is no significant difference between the Work value of low and high income of families.

\section{Methodology:}

Sample:

For this study 200 samples selected from ahmedabad city. The sample was taken as per following schedule:

1) Total no. of sample -200

(C) www.ijip.in 
2) Person's of the sample - residential doctors and bank employee.

3) Marital status of sample - married and unmarried.

4) Family type of sample - joint and nuclear.

5) Economic status of sample - low and high income of family.

6) Sampling method - Randomly selected

\section{Tools used:}

The following tools were used in the present study:

\section{Personal Data sheet:}

This personal data sheet, the information about marital status, Types of family and family income were collected.

In this research following tools are used:

\section{Work value scale:}

Work value inventory developed by super (1970) and this scale was translated into Gujarati by Jalawadiya (2002). This scale used to measure 15 work values of person. These are 45 items in this scale. All at the items had a five option. "Very importance", "importance", "general importance", "low importance" and "nothing importance" belong five option can choose any one option and marked by number $(5,4$, $3,2,1)$ In this scale there are 45 total items and three-three items for each and every work value. Sayper find out the reliability of every work value by deference types of test and he find that the reliability point 'between' 0.78 to 0.94 of every work value.

\section{Statistical Analysis:}

In this study ' $\mathrm{t}$ ' test was used for statistical analysis.

\section{Result and Discussion:}

\section{Table no.1}

Means, SDsand 't' value of Work value with reference married and unmarried person's.

$$
(N=200)
$$

(C) www.ijip.in 
The International Journal of Indian Psychology: Volume: 02 | Issue: 02 | February 2014

\begin{tabular}{|l|l|l|l|l|l|}
\hline Marital status & n & Mean & SD & t & Sign. Level \\
\cline { 1 - 3 } & 113 & 162.18 & 22.12 & \multirow{2}{*}{0.37} & NS \\
\cline { 1 - 2 } & 87 & 164.15 & 27.76 & & \\
\hline
\end{tabular}

* Work value with reference marital status (married and unmarried).

Null hypothesis HO.No.1 was constructed to get information whether any significant difference between works value of married and unmarried person.

HO.1:- There is no difference between the work value of married and unmarried person.

It can be observed the table no. 1 that mean scores with reference work value of married and unmarried person were 162.18 and 164.15. The difference between " $t$ " values is 0.37 . That " $t$ " value is not significant at 0.05 levels. It can be seen the table no 1 there was no more difference between mean of two group. So, null hypothesis 1 is accepted. And the result shows there is negligible difference between married and unmarried person on their work value.

\section{Table no 2}

Means, SDs and ' $t$ ' value of Work value with reference joint and nuclear family.

$$
(N=200)
$$

\begin{tabular}{|l|l|l|l|l|l|}
\hline Types of family & $\mathbf{N}$ & Mean & SD & t & Sign. Level \\
\hline Joint family & 89 & 161.94 & 22.64 & \multirow{2}{*}{0.75} & NS \\
\cline { 1 - 5 } & 111 & 164.54 & 26.24 & & \\
\hline
\end{tabular}

\section{Work value with reference types of family (joint and nuclear family).}

Null hypothesis HO.No.2 was constructed to get information whether any significant difference between works value of joint and nuclear family.

HO.2:- There is no difference between the work value of joint and nuclear family.

(C) www.ijip.in 
It can be observed the table no. 2 that mean scores with reference work value of joint and nuclear family were 161.94 and 164.54. The difference between " $t$ " values is 0.75. That " $\mathrm{t}$ " value is not significant at 0.05 levels. It can be seen the table no 2 there was no more difference between mean of two group. So, null hypothesis 2 is accepted. And the result shows there is negligible difference between joint and nuclear family on their work value

\section{Table no 3}

Means, SDs and 't' value of Work value with reference low and high income.

$$
(N=200)
$$

\begin{tabular}{|l|l|l|l|l|l|}
\hline Monthly income & $\mathbf{n}$ & Mean & SD & t & Sign. Level \\
\hline Low & 122 & 156.85 & 21.88 & \multirow{2}{*}{4.18} & $* *$ \\
\cline { 1 - 3 } & 78 & 173.60 & 25.46 & & \\
\hline
\end{tabular}

\section{Work value with reference monthly income (low and high).}

Null hypothesis HO.No.3 was constructed to get information whether any significant difference between works value of low and high income.

\section{Mean of Work value with reference to monthly income of persons.}

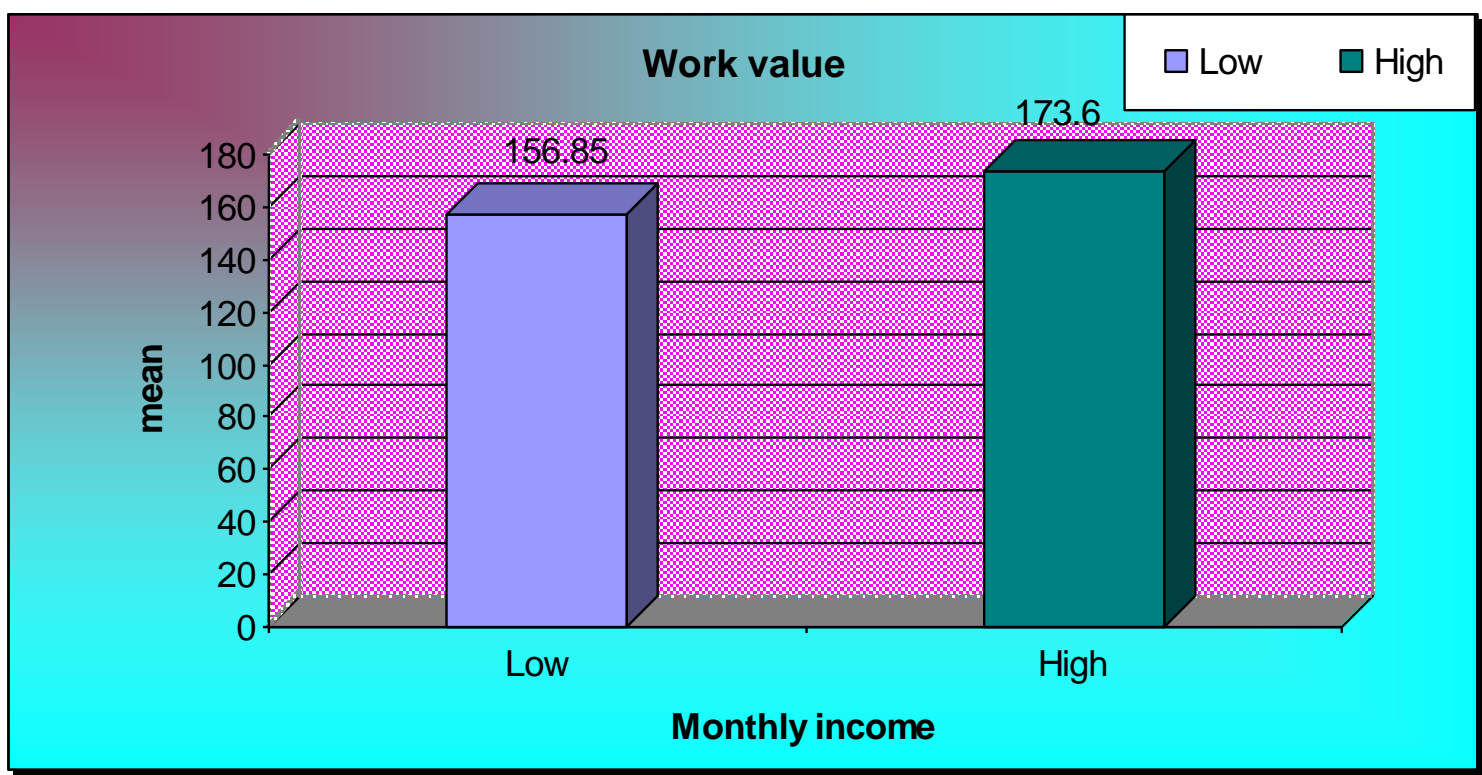

(C) www.ijip.in 
The International Journal of Indian Psychology: Volume: 02 | Issue: 02 | February 2014

\section{HO.3:- There is no difference between the work value of low and high income.}

It can be observed the table no. 3 that mean scores with reference work value of low and high income were 156.85 and 173.60. The difference between " $t$ " values is 3 That " $t$ " value is significant at 0.01 levels. It can be seen the table no 3 there was more difference between mean of two group. So, null hypothesis 3 is rejected. And the result shows there is wide difference between low and high income on their work value.

\section{Conclusion:}

1. There is no significant difference between the Work value of married and unmarried person's.

2. There is no significant difference between the Work value of joint and nuclear families.

3. The high income persons work value is better then the low incomes.

\section{References:}

1. Chandra D. (1997), "A study of perception of work value in teaching and certain non teaching occupations." unpublished PH.D thesis, Aligadh muslim university.

2. Hadi,R., and Adil, A., (2010), Job Characteristics as Predictors of Work Motivation and Job Satisfaction of Bank Employees, Journal of the Indian Academy of Applied Psychology, Vol.36, No.2, 294-299.

3. Jalavadiya, T. (2002), Unpublished Ph. D. Thesis Saurashtra University, Rajkot.

4. Priyadarshi, P. \& Kumar, P. (2009), Demographic Correlates of Work Values: A Study of Social Workers in India, Indian Journal of Industrial Relations, Volume 45 Issue 2.

5. Super, D. E.,(1970), "Work Values Inventory bostam", Houghton miffin co.

(C) www.ijip.in 